\title{
OA12.03. Integrative medicine at academic health centers: a survey of clinicians' educational backgrounds and practices
}

\author{
G Ehrlich*, T Callender, B Gaster \\ From International Research Congress on Integrative Medicine and Health 2012 \\ Portland, Oregon, USA. 15-18 May 2012
}

\section{Purpose}

Integrative medicine is a relatively new field which seeks to combine a wide range of conventional and nonconventional approaches to patient care. Many academic health centers have now established integrative medicine clinics, yet little is known about the clinicians who practice at them.

\section{Methods}

We conducted a nationwide survey of clinicians (MD's, DO's, PA's, and nurse practitioners) who practice at integrative medicine clinics which are affiliated with academic health centers, seeking to characterize their educational backgrounds, clinical practices, and participation in research and education activities.

\section{Results}

We received completed surveys from 136 of 162 clinicians ( $84 \%$ response rate). The integrative therapies that clinicians most often reported providing themselves were breathing exercises (66\%), herbal medicine prescribing (61\%), meditation (44\%), and functional medicine $(34 \%)$. The integrative therapies that clinicians most often referred their patients for were acupuncture (96\%), massage (92\%), yoga (85\%), and meditation (79\%). Respondents reported spending a mean of $20 \%$ of their time training medical students, and $63 \%$ had participated in research in the past year.

\section{Conclusion}

This survey provides the first national assessment of clinicians practicing integrative medicine at academic health centers. These clinicians employ a wide variety of

University of Washington, Seattle, USA complementary and alternative therapies and appear involved in the research and education missions of their academic health centers.

Published: 12 June 2012

doi:10.1186/1472-6882-12-S1-O47

Cite this article as: Ehrlich et al:: OA12.03. Integrative medicine at academic health centers: a survey of clinicians' educational backgrounds and practices. BMC Complementary and Alternative Medicine 2012 12(Suppl 1):O47.
Submit your next manuscript to BioMed Central and take full advantage of:

- Convenient online submission

- Thorough peer review

- No space constraints or color figure charges

- Immediate publication on acceptance

- Inclusion in PubMed, CAS, Scopus and Google Scholar

- Research which is freely available for redistribution
() Biomed Central

\section{(Ciomed Central}

C 2012 Ehrlich et al; licensee BioMed Central Ltd. This is an Open Access article distributed under the terms of the Creative Commons Attribution License (http://creativecommons.org/licenses/by/2.0), which permits unrestricted use, distribution, and reproduction in any medium, provided the original work is properly cited. 